\title{
Cool-Dry Season Depression in Gas Exchange of Canopy Leaves and Water Flux of Tropical Trees at the Northern Limit of Asian Tropics
}

\section{Zafar Siddiq ( $\sim$ zafareco@outlook.com )}

Government College University Lahore

\section{Yong-Jiang Zhang}

University of Maine Orone 04469 USA

\section{Research Article}

Keywords: Carbon assimilation, Rainforest, canopy gas exchange, Dipterocarps, tropical China

Posted Date: September 7th, 2021

DOl: https://doi.org/10.21203/rs.3.rs-223937/v1

License: (c) (1) This work is licensed under a Creative Commons Attribution 4.0 International License.

Read Full License

Version of Record: A version of this preprint was published at Plant Ecology on October 27th, 2021. See the published version at https://doi.org/10.1007/s11258-021-01197-3. 


\section{Abstract}

Trees on the northern boundary of Asian tropics experience hot-humid and cool-dry seasons, but little is known about their seasonal dynamics in canopy physiology. We used a canopy crane to reach the canopy of nine tropical tree species and measured canopy leaf gas exchange, water status, and trunk sap flux during the hot-humid and cool-dry seasons in Xishuangbanna, China. We found that most tree species exhibited significant reductions in maximum photosynthetic rate $\left(A_{\max }\right)$, stomatal conductance $\left(g_{\text {smax }}\right)$, predawn and midday leaf water-potentials, and maximum sap flux density in the cool-dry season. Compared to the hot-humid season, $A_{\max }$ declined by $19 \%-60 \%$, and maximum water flux declined by $-14 \%$ (an increase) to $42 \%$. The cool-dry season decline in $A_{\max }$ of four species can be partly explained by an increased stomatal limitation (decreased $g_{\text {smax }}$ and intercellular $\mathrm{CO}_{2}$ concentrations). Therefore, a predicted increase in drought in this region may decrease the carbon sequestration and productivity of these forests. We did not find a tradeoff between performance ( $A_{\max }$ in the hot-humid season) and persistence through the cool-dry season; species with higher $A_{\max }$ in the hot-humid season did not show higher percent seasonal declines in the cool-dry season. $A_{\max }$ was significantly and positively associated with the trunk spa flux for both seasons but the association was weak in the cool-dry season. Thus, our results suggest that some tradeoffs and trait associations are environment-dependent. Our results are important to understand carbon and water fluxes of seasonal tropical forests and their responses to environmental changes.

\section{Introduction}

The dynamics of tree carbon and water fluxes are driven by environmental conditions such as temperature, solar radiations, and relative humidity (Fauset et al. 2019; Dusenge, and Way 2017; Way et al., 2015). Changes in these environmental conditions lead to changes in canopy leaf physiology which can be species-specific (Aragao et al., 2014; Chen and Cao 2015; Siddiq et al. 2017). Tree leaf photosynthesis $(A)$ and water fluxes are sensitive to changes in environmental conditions, and reach their maximum values under optimum conditions (Tucci et al. 2010; Yang et al. 2012; Zhang et al. 2014a; Gitelson et al, 2014). In the tropics, the optimum conditions are observed during moderate atmospheric temperature and humidity, which create the suitable driving force (vapor pressure deficit) for water fluxes (Siddiq et al., 2017) and suitable temperature for photosynthesis (Cao et al., 2006; Kumagai et al., 2006; Slot et al., 2017; Slot and Winter 2017). In tropical areas with a seasonality in temperature and/or rainfall, (e.g. marginal tropics) the reduction of temperature and/or rainfall during the cool and/or dry season can result in reduced carbon and water fluxes (Vongcharoen et al., 2018; Frenne et al., 2019; Santanoo et al., 2019). Forests at marginal tropics, e.g., those at the northern edge of Asian tropics, are characterized by a seasonality in temperature and rainfall, which results in a hot-humid season and a cool-dry season. These seasonal changes will change the canopy leaf physiology which has not been well-studied until now. These forests are strong carbon sinks and contribute significantly to the global carbon cycle (Zhang et al., 2006, Tan et al., 2012; Cristiano et al., 2014; Zhang et al., 2016), but the physiological mechanisms explaining their high carbon sink function and seasonal dynamics are not well-understood. 
The marginal tropical rainforests in Xishuangbanna, China, which is on the northern boundary of Asian tropics, are typical Asian tropical rainforests in terms of species composition, phenology, and an important component of the Indo-Burma diversity hotspot (Myers et al. 2000, Cao et al. 2006; Hua 2013). They are also strong carbon sinks (Zhang et al., 2006) contributing significantly to the global carbon cycle. The tropical forests of this region are under the threat of degradation due to global warming, increasing drought, decreasing fog persistence, and the introduction of exotic species for commercial uses (Singh et al., 2019; Zhang et al., 2014a; Qiu 2010; Li et al., 2006). All these changes may significantly alter the water and carbon cycles of the region. For instance, the carbon fixation of the forests was significantly reduced in this region due to a drought in 2010 (Zhang et al., 2012). An understanding of water and carbon fluxes of trees from this region under different environmental conditions will help to predict their response to climate change including an increase in climate variability and develop effective management strategies.

Although there are some studies reporting the seasonal changes in photosynthesis of crops and small trees (Zhang et al., 2014a) and ecosystem-level carbon fluxes of the marginal Asian tropical forests (Zhang et al., 2006), more mechanistic studies are needed to understand their canopy physiology in responding ambient seasonal environmental changes. For instance, temperate plants are found to follow a general tradeoff between maximum photosynthesis in the favorable season, and persistence through the unfavorable season; species with higher maximum photosynthetic performance $\left(A_{\max }\right)$ in the favorable season show higher percent seasonal declines in $A_{\max }$ during the cold or dry season (Zhang et al., 2017). However, it is unknown whether trees from the marginal tropics with less seasonality compared to the temperate regions follow the same tradeoff. Understanding tree physiology and its seasonal dynamics of marginal tropical forests will also help to predict the response of temperate forests that are adjacent to them to future warming, and the response of tropical forests to a predicted increase in climate variability (e.g. seasonal drought or dry spells). Further, a more physiological understanding of these forests can improve the performance of the global land surface models, which are used to understand and predict the global water and carbon fluxes in a changing climate. Marginal tropical and subtropical forests are under-represented in these models (Pan et al., 2020; Gentine et al., 2019; Li et al., 2018).

It has been observed that photosynthetic carbon gain and water flux are coupled (Cowan \& Farquhar 1977; Santiago et al., 2004, Brodribb and Feild, 2000; Fauset et al., 2019; Siddiq et al., 2019) because both processes are regulated by the stomata. A large water flux enabled by a high transport capacity will result in a high leaf water potential (less negative) during active transpiration at a given evaporative demand, which can potentially facilitate photosynthetic gas exchange (Landsberg et al., 2017). However, environmental conditions of the habitat can shift the coupling between water transport and leaf gas exchange (Sack et al., 2005), and therefore this coupling can also be potentially changed due to seasonal changes in environmental conditions. The evaporative cooling strategies will adjust according to seasonal changes in temperature. In the cool season, the needs for cooling through canopy transpiration are less, while in the hot-humid season the canopy needs a significant amount of evaporative cooling to avoid heat damage. Additionally, water flux and stomatal conductance may not be the major limiting 
factors on photosynthesis in the cool season as tropical trees can be sensitive to chilling induced photodamage (Levitt 1980; Dungan et al., 2003; Huang et al., 2010; Zhang et al., 2014b; Yang et al., 2017). Therefore, water flux and photosynthesis are not necessarily coupled in the unfavorable season. The other factors such as leaf phenology and leaf age that influence leaf photosynthesis (Kitajima et al., $1997 ; 2002)$ can also alter the coupling between water flux and carbon gain in the cool-dry season, as these forests have species with a range of leaf life spans including both evergreen and deciduous species. Generally, how this coupling responds to environmental changes, and how it shifts in different seasons are not well-understood.

Here we accessed the canopy of tropical trees in Xishuangbanna with a canopy crane, and measured canopy leaf carbon assimilation and water fluxes in the hot-humid and cool-dry seasons. The main objectives of the present study were: 1) to quantify the seasonal changes in canopy photosynthesis and water flux of trees at the northern limit of Asian tropics; 2 ) to test whether the potential cool-dry season declines in $A_{\max }$ of some species of this region is due to increased stomatal limitation, and whether the seasonal changes in environmental conditions shift the coordination between water flux and photosynthesis; and 3) to test whether there is a tradeoff between maximum photosynthetic performance ( $A_{\max }$ in the hot-humid season) and persistence through the cool-dry season (less percent decline in $A_{\max }$ ) across species. We hypothesized that the species with high rates of carbon fixation during the hot-humid season have higher seasonal declines in the cool and dry season according to the performance vs endurance tradeoff (Zhang et al., 2017). It was also hypothesized that most tree species will show significant declines in photosynthesis and water use, mainly caused by an increased stomatal limitation due to decreased water availability. We also hypothesized that the coordination between photosynthesis and water flux will be weaker during the cool-dry season due to the increased limitation of factors other than water transport (e.g. photochemistry) on photosynthesis.

\section{Materials And Methods}

\section{Study site and species}

The experimental set-up for this study was established in Xishuangbanna Tropical Botanical Garden (XTBG; $21^{\circ} 54^{\square} \mathrm{N}, 101^{\circ} 46^{\square} \mathrm{E}, 580 \mathrm{~m}$ a.s.I.), southern Yunnan Province, Southwest China. This region has a typical tropical monsoon climate and hence a pronounced hot-humid season with plenty of rains from May - October and the dry season from November to April, which can be cool-dry season from December to February and hot-dry season from March-April. The mean annual precipitation is $1560 \mathrm{~mm}$, approximately $80 \%$ of which falls during the wet season. The mean annual temperature of the study site is $21.7^{\circ} \mathrm{C}$ (Cao et al. 2006. In this study, we selected 26 individual trees from 9 species in plantation stands of 40-years-old (Table 1). Among the nine studied six species i.e, Hopea hainanensis, Shorea assamica, Vatica magachapoi, Mesua ferrea, Dalbergia odorifera, and Pterocarpus indicus are naturally distributed in the southern China while the other three species; Anisoptera laevis, Dipterocarpus alatus and Swietenia mahagoni are exotic trees. The former two species are naturally distributed in northern 
Thailand and adjoining tropical areas while Swietenia mahagoni is naturally found in tropical Caribbean islands of the United States. Among the nine species, six are evergreen while the rest are deciduous (Table 1). The canopy physiological measurements were carried out in September 2012 for the hot-humid season, while the cool-dry season measurements were done during the first week of January 2013. All the deciduous species start shedding their leaves at the end of February or the beginning of March and start flushing new leaves in mid-April.

Table 1

List of species studied, their scientific names, abbreviations, family, DBH range, and replicates. Asterisk indicates the exotic species, while the rest are indigenous to southern China.

\begin{tabular}{|c|c|c|c|c|c|}
\hline Scientific Name & Abbreviation & Family & $\begin{array}{l}\text { Leaf } \\
\text { Phenology }\end{array}$ & $\begin{array}{l}\text { DBH } \\
\text { range } \\
\text { (cm) }\end{array}$ & $\begin{array}{l}\text { Number } \\
\text { of trees }\end{array}$ \\
\hline *Anisoptera laevis Ridl. & $\mathrm{Al}$ & Dipterocarpaceae & Evergreen & $31,33,37$ & 3 \\
\hline $\begin{array}{l}\text { *Dipterocarpus alatus } \\
\text { Roxb. Ex G.Don }\end{array}$ & $\mathrm{Da}$ & Dipterocarpaceae & Evergreen & $30,37,58$ & 3 \\
\hline $\begin{array}{l}\text { Hopea hainanensis Merr. \& } \\
\text { Chun }\end{array}$ & $\mathrm{Hh}$ & Dipterocarpaceae & Evergreen & $19,29,32$ & 3 \\
\hline Shorea assamica Dyer & $\mathrm{Sa}$ & Dipterocarpaceae & Evergreen & 17,20 & 2 \\
\hline Vatica magachapoi Blanco & $\mathrm{Vm}$ & Dipterocarpaceae & Evergreen & 20,22 & 3 \\
\hline Mesua ferrea $\mathrm{L}$. & Mf & Calophyllaceae & Evergreen & 16,22 & 4 \\
\hline $\begin{array}{l}\text { Dalbergia odorifera } \\
\text { T.C.Chen }\end{array}$ & Do & Leguminosae & Deciduous & $18,19,23$ & 3 \\
\hline Pterocarpus indicus Willd. & $\mathrm{Pi}$ & Leguminosae & Deciduous & 20,31 & 2 \\
\hline $\begin{array}{l}\text { *Swietenia mahagoni (L.) } \\
\text { Jacq. }\end{array}$ & Sm & Meliaceae & Deciduous & $31,43,55$ & 3 \\
\hline
\end{tabular}

\section{Seasonal differences of climatic variables}

There were distinct differences in the atmospheric temperature between the hot-humid and cool-dry seasons of the studied year. The mean daily temperature during the cool-dry season was $18^{\circ} \mathrm{C}$, while it was $25^{\circ} \mathrm{C}$ in the hot-humid season. The mean vapor pressure deficit (VPD) during the cool-dry season was $0.3 \mathrm{kPa}$ while in the hot-humid season it was $0.73 \mathrm{kPa}$. The average solar radiation in the cool-dry season was $600 \mu \mathrm{mol} \mathrm{m} \mathrm{m}^{-2} \mathrm{~s}^{-1}$ while in the hot-humid season it was $640 \mu \mathrm{mol} \mathrm{m} \mathrm{m}^{-2} \mathrm{~s}^{-1}$. The duration of daylight with $>100 \mu \mathrm{mol} \mathrm{m}^{-2} \mathrm{~s}^{-1}$ during the hot-humid season is from 9:00 - 19:00, while during the cool-dry season it was 10:00 - 18:00. The rainfall during the hot-humid months was $>200 \mathrm{~mm}$ per month while in the cool-dry season it was $<100 \mathrm{~mm}$ per month (Figure $1 \mathrm{a}-\mathrm{d}$ ).

\section{Canopy gas exchange and leaf water potentials}


To access the canopies with the height range of 25 - $35 \mathrm{~m}$ we used a canopy crane mounted on a truck. Trees close to the edges of the stands were not used to minimize potential edge effects. The maximum (light-saturated) leaf photosynthesis $\left(A_{\mathrm{max}}, \mathrm{m} \mathrm{mol} \mathrm{m}^{-2} \mathrm{~s}^{-1}\right)$ and stomatal conductance $\left(g_{\mathrm{smax}} ; \mathrm{mol} \mathrm{m}^{-2} \mathrm{~s}^{-1}\right)$, were measured using a portable photosynthesis measurement system (LI-6400; LI-COR, Nebraska, USA) under ambient conditions on sunny days for both hot-humid and cool-dry seasons. The maximum gas exchange was measured between 09:00 and 11:00. The chamber temperature during the measurement time of the hot-humid season was approximately $23^{\circ} \mathrm{C}$, and the leaf to air vapor pressure deficit (VPD) was approximately $1.0 \mathrm{kPa}$. During the cool-dry season the chamber temperature was $17^{\circ} \mathrm{C}$ and the leaf to air vapor pressure deficit was $0.7 \mathrm{kPa}$. The PPFD within the chamber was set at $1000 \mu \mathrm{m}^{-2} \mathrm{~s}^{-1}$ as the maximum gas exchange rates were achieved at this level and to avoid photoinhibition. For each tree, six to eight new fully-developed mature leaves from different sun-exposed canopy-top terminal branches of two to four individuals per species were selected to measure canopy gas exchange at the top of the canopy. For each tree, six to eight stable values of photosynthetic rate and stomatal conductance were logged and stored in the LI-6400 instrument and the average value of each species was calculated. Intrinsic water use efficiency was calculated by dividing the photosynthetic rate with stomatal conductance (Farquhar et al., 1982). The intercellular values of carbon $\left(C_{i} \mathrm{mmol} \mathrm{mol}^{-1}\right)$ were also obtained from the LI-6400 while measuring the gas exchange. The leaf water potentials were measured on-site from five to six leaves per tree using a pressure chamber (PMS, Albany, OR, USA). Predawn leaf samples were collected and measured in the field between 06:00 and 07:00, whereas midday samples were collected between $12: 30$ and $14: 30$ on sunny days.

\section{Sap flow and Meteorological data}

We used the daily maximum sap flow data (water flux; peak sap flux density during the day; $\mathrm{g} \mathrm{m}^{-2} \mathrm{~s}^{-1}$ ) of hot-humid and cool-dry seasons from the sap flow measurements for the same trees that were used to measure canopy photosynthetic gas exchange. Sap flow was measured using Granier- type heat dissipation sap flow sensors (Granier, 1987) from 2012 to 2013, and the daily maximum sap flow data of the same days with canopy gas exchange measurements were used for this study. The technique involves the heating of one sensor using an electrical source, while the other sensor was not heated and used as the reference sensor. The temperature difference between these two sensors was used to calculate the sap flux density. The details are mentioned in Siddiq et al., (2019). The original Granier equation was calibrated to calculate the sap flux density, as that Granier equation can substantially underestimate the sap flux density of tropical trees (Siddiq et al., 2017). The hourly mean meteorological data i.e, temperature, solar radiations, relative humidity, and rainfall were collected from the Xishuangbanna Tropical Rain Forest station, situated about 900 meters away from the study site.

\section{Data analysis}

The effect of species and season on canopy gas exchange $\left(A_{\max }\right.$ and $\left.g_{\text {smax }}\right)$ were analyzed by a two-way ANOVA using SPSS (IBM version 19). The differences in maximum canopy photosynthesis $\left(A_{\max }\right)$, 
stomatal conductance $\left(g_{\text {smax }}\right)$, water use efficiency, intercellular $\mathrm{CO}_{2}$ concentration, pre-dawn and midday leaf water potentials between the two seasons, for the individual species, were analyzed using a ttest. Duncan's method was used for comparison of mean $A_{\max }$ and $g_{\text {smax }}$ during hot-humid and cool-dry seasons across the studied deciduous and evergreen species. A linear regression was fitted to the relationships between percentage decline in $A_{\max }$ and $g_{\text {smax }}$ from the hot-humid to the cool-dry season to test whether the potential decline in $A_{\max }$ was associated with decrease $g_{\mathrm{smax}}$. The relationship between $A_{\text {max }}$ of hot-humid season and the absolute or percent decline in $A_{\max }$ during the cool-dry season was also fitted with a linear regression to test the potential tradeoff between maximum performance and persistence through the cool-dry season. The association of maximum photosynthetic rate or stomatal conductance with the maximum sap flux density was analyzed with a linear regression to test the coupling between flux and photosynthesis for both seasons. The generation of graphics and regression analyses were carried out using the Sigmaplot software (version-12.5; Systat Software Inc. USA).

\section{Results}

\section{Variations across species}

The studied species showed high variations in canopy photosynthetic gas exchange $\left(A_{\max }\right.$ and $\left.g_{\text {smax }}\right)$, water use efficiency, and midday leaf water potentials in both the hot-humid and cool-dry seasons. The significant effect of species and season, and species-season interaction was observed among the studied species (Table 2). Further, evergreen species had significantly higher $A_{\max }$ during both the hothumid and cool-dry seasons (Table 3 ). The $g_{\mathrm{s} \text { max }}$ of the hot-humid season was significantly higher in evergreen than in deciduous trees, while no significant difference was detected between the two groups of trees in the cool-dry season (Table 3 ). The highest $A_{\max }$ across species were found in $D$. alatus, i.e, $18.71 \mu \mathrm{mol} \mathrm{m}^{-2} \mathrm{~s}^{-1}$ and $11.59 \mu \mathrm{mol} \mathrm{m} \mathrm{m}^{-2} \mathrm{~s}^{-1}$ in the hot-humid and cool-dry seasons, respectively. The lowest $A_{\max }$ in the hot-humid season was observed in $S$. assamica, $\left(6.85 \mu \mathrm{mol} \mathrm{m}^{-2} \mathrm{~s}^{-1}\right)$. In the cool-dry season, the lowest $A_{\max }$ was found in $M$. ferrea, which was $3.24 \mu \mathrm{mol} \mathrm{m}^{-2} \mathrm{~s}^{-1}$ (Fig. 2). The highest stomatal conductance was found in $D$. alatus, which were 0.37 and $0.20 \mathrm{~mol} \mathrm{~m}^{-2} \mathrm{~s}^{-1}$ during the hothumid and cool-dry seasons, respectively. The lowest $g_{\mathrm{s}-\max }$ during the hot-humid season was found in $S$. assamica $\left(0.039 \mathrm{~mol} \mathrm{~m}^{-2} \mathrm{~s}^{-1}\right)$. In the cool-dry season, the lowest $g_{\mathrm{s} \text { max }}$ was found in in $M$. ferrea, which was $0.031 \mathrm{~mol} \mathrm{~m}^{-2} \mathrm{~s}^{-1}$. The species also showed high variations in their water use efficiency in both seasons, ranging from 49.42-204.65 $\mu \mathrm{mol} \mathrm{m}^{-1}$ during the hot-humid season, and 55.45-190.04 $\mu \mathrm{mol}$ $\mathrm{m}^{-1}$ in the cool-dry season. The intercellular $\mathrm{CO}_{2}$ also varied highly across species. In the hot-humid season it ranged from $100-350 \mathrm{~m} \mathrm{~mol} \mathrm{~mol}^{-1}$, while in cool-dry season, it ranged from $174-28 \mathrm{~m} \mathrm{~mol}$ $\mathrm{mol}^{-1}$ (Fig. 2c, d). The pre-dawn leaf water potential ranged from $-0.26 \mathrm{MPa}(D$. alatus) to $-0.53 \mathrm{MPa}(A$. laevis) in the hot-humid season, and it ranged from $-0.46 \mathrm{MPa}$ ( $M$. ferrea) to $-0.81 \mathrm{MPa}$ ( $V$. magachopoi) in the cool-dry season. The midday leaf water potential ranged from $-0.62 \mathrm{MPa}(D$. alatus) to $-2.0 \mathrm{MPa}$ 
(M. ferrea) in the hot-humid season, and it ranged from - 1.0 MPa (D. alatus) to $-2.56 \mathrm{MPa}$ (S. assamica) in the cool-dry season.

Table 2

Two-way ANOVA results for the effect of species and season on photosynthetic rate and stomatal conductance.

\begin{tabular}{|lllll|}
\hline Predictor & SS & df & $\mathbf{F}$ & $\boldsymbol{P}$ \\
\hline Species & & & & \\
\hline$A_{\max }$ & 14700.47 & 8 & 1429.12 & $<0.0001$ \\
\hline$g_{\text {smax }}$ & 9.46 & 8 & 2651.2 & $<0.0001$ \\
\hline Season & & & & \\
$A_{\max }$ & 3393.76 & 1 & 2639.4 & $<0.0001$ \\
$g_{\text {smax }}$ & 0.250 & 1 & 559.055 & $<0.0001$ \\
\hline Species: season & & & & \\
\hline$A_{\max }$ & 7833.78 & 8 & 76.19 & $<0.0001$ \\
\hline$g_{\text {smax }}$ & 1.879 & 8 & 526.31 & $<0.0001$ \\
\hline
\end{tabular}

Table 3

Duncan's test for comparison of mean $A_{\max }$ and $g_{\text {smax }}$ during hothumid and cool-dry season across the studied deciduous and evergreen species.

\begin{tabular}{|llll|}
\hline Season & $\boldsymbol{A}_{\max }$ (Deciduous, Evergreen) & F-value & P-value \\
\hline Hot-humid & $9.54( \pm 1.16), 12.46( \pm 4.81)$ & 61.17 & $<0.001$ \\
\hline Cool-dry & $6.33( \pm 1.71), 7.384( \pm 3.905)$ & 18.26 & $<0.01$ \\
\hline Season & $g_{\text {smax }}$ (Deciduous, Evergreen) & & \\
\hline Hot-humid & $0.06( \pm 0.002), 0.20( \pm 0.01)$ & 221.95 & $<0.001$ \\
\hline Cool-dry & $0.10( \pm 0.003), 0.11( \pm 0.002)$ & 3.75 & 0.053 \\
\hline
\end{tabular}


The seasonal dynamics in maximum photosynthetic rate $\left(A_{\max }\right)$, stomatal conductance $\left(g_{\mathrm{s} \text { max }}\right)$ differed among individual species (Table 2). Significant seasonal declines in the values of $A_{\max }$ was found in six out of the nine species, while the other three species did not show significant change (Fig. 2a). Significant seasonal declines in $g_{\mathrm{s} \text { max }}$ were found in only four species. Two species showed significant increases in $g_{\mathrm{s} \text { max }}$ in the cool-dry season, four species showed significant declines of $g_{\mathrm{s} \text { max }}$ in the cool-dry season, while the remaining three species showed no change (Fig. 2b). The percentage of photosynthesis reduction in the cool-dry season compared to the hot-humid season ranged from $19 \%$ in S. mahagoni to $60 \%$ in M. ferrea. Three species showed a significant decline in water use efficiency in the cool-dry season compared to the hot-humid season, while two species showed significant increases and the other three species showed no change (Fig. 2c). Four species showed significant declines in the intracellular $\mathrm{CO}_{2}$ concentration in the cool-dry season compared to the hot-humid season, while three species showed significant increases and two species showed no change (Fig. 2d). For daily maximum sap flux density, five out of the nine species showed significant declines in the cool-dry season compared to the hot-humid season, while the other four species ( $D$. odorifera, $H$. hainanensis, $S$. assamica and $S$. mahagoni) did not show significant differences between the two seasons (Fig. 3). A significant decline in pre-dawn leaf water potential in the cool-dry season (compared to the hot-humid) was found in six out of the nine species (not in A. laevis, D. odorifera and M. ferrea). A significant cool-season decline in midday leaf water potential was found in seven species but not in M. ferrea and P. indicus (Fig. 4a,b).

\section{Relationship Between Water Flux And Photosynthetic Gas Exchange}

A significant and positive relationship $\left(R^{2}=0.50 ; P<0.01\right)$ was found between the percent decline of $A_{\text {max }}$ and the percent decline in $g_{\mathrm{s}}$ from the hot-humid to the cool season (Fig. 5). A significant and positive relationship was also found between maximum sap flux density and photosynthetic rate in both the hot-humid and cool-dry seasons, although the relationship was weaker during the cool-dry season as compared to that of the hot-humid season (Fig. 6a). There was also a significant and positive relationship between maximum sap flux density and stomatal conductance in the hot-humid season (Fig. 6b). The relationship between sap flux density and stomatal conductance during the cool-dry season was not significant $\left(\mathrm{R}^{2}=0.64, P>0.01\right.$, Fig. $\left.6 \mathrm{~b}\right)$. No relationship between the $A_{\max }$ of the hot-humid season and the percent decline in $A_{\max }$ from the hot-humid to the cool-dry season has been found across species (relationship not shown).

\section{Discussion}

Our study quantified the seasonal dynamics in canopy leaf photosynthetic gas exchange, and trunk water flux of nine tree species at the northern limit of the Asian tropics. The studied tree species showed high variations in canopy photosynthetic performances and trunk water flux, as well as their seasonal changes (two-way ANOVA; Table 2). This pattern suggests diversified responses of trees in the marginal tropics to 
the seasonal unfavorable conditions and diverged strategies in achieving high annual carbon assimilation. Our results did not support the hypothesis that species with high photosynthetic rates in the hot-humid season will have more percent declines in cool-dry season, i.e, a photosynthetic performance vs. persistence tradeoff, as found in temperate plants (Zhang et al., 2017). The absence of a tradeoff between photosynthetic performances under favorable conditions and persistence through the unfavorable season (low seasonal declines) in marginal tropical trees could be because the "stress" level in the cool-dry season of this region is not strong enough to make this tradeoff detectable. Also, the leaf age effects (Field 1983, 1987, Kitajima et al., 1997, 2002) and potential different strategies in responding to seasonal stress between evergreen and deciduous species may confound the potential tradeoff.

Six out of nine species studied showed significant declines in the maximum photosynthesis rate in the cool-dry season. However, despite significant declines, the cool season canopy photosynthetic rate of the studied species ranged from $3.24 \mu \mathrm{mol} \mathrm{m} \mathrm{m}^{-2} \mathrm{~s}^{-1}$ to $11.59 \mu \mathrm{mol} \mathrm{m} \mathrm{m}^{-2} \mathrm{~s}^{-1}$, indicating significant amount of net carbon gain during the cool-dry season. This finding provides a physiological explanation of the ecosystem-level carbon sequestration during the cool-dry season in this region and their great contribution to the global carbon cycles (Zhang et al., 2006). Furthermore, soil and tree nocturnal respiration is lower due to lower temperatures during the cool-dry season (Barbour et al., 2005; Anderegg et al., 2015; Siddiq and Cao 2018), which can also contribute towards more positive ecosystem carbon accumulation in the cool-dry season. The water loss of the trees, indicated by leaf stomatal conductance and tree sap flux density, also declined during the cool-dry season in five species. This could be beneficial to these trees for water conservation in the cool-dry season. Water conservation in the cool-dry season is important for trees as most tree species experienced some degree of drought stress indicated by predawn water potentials being lower than $-0.5 \mathrm{MPa}$, and as high as $-0.8 \mathrm{MPa}$. The leaf water potentials were generally reflecting the rainfall pattern; a significantly lower rainfall in the cool-dry season will result in dryer soils and therefor lower leaf water potentials. Interestingly, the VPD in the cool-dry season was lower compared to the hot-humid season despite lower rainfall (Fig. 1). Lower VPD and thus lower transpirational demand can be the reason for lower water flux in the cool dry season (Fig. 3; Siddiq and Cao, 2016). Meanwhile, these results suggest that the lower midday leaf water potentials in the cool-dry season compared to the hot-humid season cannot be explained by changes in VPD.

Our results suggest that the cool-dry season decline in $A_{\max }$ in some tree species can be explained by an increased stomatal limitation. The percent decline in $A_{\max }$ in the cool-dry season is significantly associated with the percent decline in $g_{\mathrm{s}}$, suggesting the decline in $A_{\max }$ can be at least partly explained by increased stomatal limitation. This is at least true for four species (A. laevis, $D$. alatus, $M$. ferrea and $V$. magachopai). For these four species showing significant seasonal declines in $A_{\max }$, their $g_{\mathrm{smax}}$ and $C_{i}$ also declined significantly in the cool-dry season compared to the hot-humid season (Fig. 2). For them, decreased $g_{\mathrm{s}}$ is limiting $\mathrm{CO}_{2}$ uptake, resulting in lower $C_{i}$ and $A_{\max }$ in the cool-dry season. For the other two showing significant declines in $A_{\max }\left(P\right.$. indicus, $H$. hainanensis), their $g_{\text {smax }}$ and $C_{i}$ showed increases or no change in the cool season. Therefore, their decreases in $A_{\max }$ cannot be explained by increased stomatal limitation but could probably result from low-temperature induced photoinhibition, as found in 
crops and tree seedlings in the region (Huang et al. 2010; Zhang et al., 2014b), or reduced photosynthetic carboxylation capacity under lower temperatures (Kumarathunge et al. 2019). In addition, leaf age may also be a possible factor explaining seasonal declines in $A_{\max }$ (Field 1983, 1987, Kitajima et al., 1997, 2002). A recent study (Bielczynski 2017) emphasizes that both increased leaf and plant ages can cause decline in photosynthetic performance. For evergreen trees, because they continuously flush leaves throughout the year in this region and we selected newly-fully-developed leaves for measurements, the leaf age effect on $A_{\max }$ should be minor. For one deciduous species showed a seasonal declines in $A_{\max }$ ( $P$. indicus) but not in $g_{\mathrm{s} \text { max }}$ the age effect could at least partly explains the decline in $A_{\max }$ because the leaves were 6-week-away from shedding during the cool-dry season measurements.. However, no declines in $A_{\text {max }}$ were found in the other two deciduous species. Notably, two species with more southern and warmer native distribution limits ( $A$. laevis and $D$. alatus, see materials and methods) showed the highest $A_{\text {max }}$ among all the studied species in both the hot-humid and cool-dry seasons. This suggests their high physiological plasticity in responding to changes in temperatures and contradicts our general understanding that species with warmer native habitats have lower resistance to low temperatures (Armando et al., 2016; Korner, 2016).

Our study found a seasonal shift in the coupling between water flux and photosynthesis, and the coupling is weakened during the cool-dry season. The coupling of canopy photosynthesis and trunk water flux during both the hot-humid and cool-dry seasons, indicate the canopy level synchronization of these two processes, supporting Drake et al. (2018). However, although the photosynthetic rate and the trunk water flux remained significantly associated during the cool-dry season, the coefficient of the relationship was lower compared to the hot-humid season. The same pattern was found for the relationship between stomatal conductance and trunk water flux. It was significant in the hot-humid season, but became not significant during the cool-dry season. The closer coupling between canopy photosynthesis and trunk water flux during the hot-humid season could be because in the cool-dry season there may be more other limiting factors on canopy photosynthesis rather than water supply, e.g. chilling-induced decline in leaf photosynthetic electron transport (Huang et al., 2010; Zhang et al., 2014b) and carboxylation activity (Kumarathunge et al. 2019), and the leaf age effect (Field 1983, 1987, Kitajima et al., 1997, 2002).

\section{Conclusion}

In conclusion, the studied trees showed a high variation in seasonal dynamics of canopy leaf gas exchange at the northern limit of Asian tropics. Three species showed no seasonal declines in $A_{\max }$ while the rest also maintained positive carbon assimilation during the cool-dry season,, suggesting that the forests are productive throughout the year. These results also provide a physiological explanation for the carbon sink function of the forests in the cool-dry season (Zhang et al., 2006). The seasonal declines in gas exchange are associated with increased stomatal limitation in some but not all the tree species, suggesting that further warming and increased VPD may have different impacts on limiting photosynthesis of different species. Variations in the response to seasonal changes in temperatures and 
soil water content also suggest a potential shift in species composition of the forests under climate change. Further, some of the tree species showed water stress with predawn water potentials as negative as -0.8 MPa in the cool-dry season, indicating that an increase in drought in this region (Jia et al., 2016; Zhang et al., 2019) could further exacerbate the water stress and decrease carbon sequestration potential of tropical forests in this region. In addition, we did not find the hypothesized tradeoff between maximum photosynthetic performance under favorable conditions and persistence through the unfavorable season as found in temperate plants. We also found a seasonal shift in the coupling between water flux and photosynthesis. Therefore, our study confirms that a lot of trait correlations and tradeoffs are environment or climate-dependent (Sack et al., 2005).

\section{Declarations}

\section{Acknowledgements}

The authors are grateful to the horticulture department of XTBG for permitting the experiment and also providing the crane to access the canopy. The Xishuangbanna Tropical Rain Forest Climatic Station is also acknowledged for providing the climatic data. The research work was financially supported by National Natural Science Foundation of China (Projects: 31170399, 31470469). The authors are also thankful to Marlys Rietdyk for editing the language.

Competing interests: The authors declare no competing interests.

\section{References}

1. Anderegg, W. R., A. P. Ballantyne, W. K. Smith, J. Majkut, S. Rabin, C. Beaulieu, R. Birdsey, J. P. Dunne, R. A. Houghton, R. B. Myneni, Y. Pan, J. L. Sarmiento, N. Serota, E. Shevliakova, P. Tans, and S. W. Pacala (2015) Tropical nighttime warming as a dominant driver of variability in the terrestrial carbon sink. Proceedings of National Academy of Sciences USA 112:15591-15596.

2. Aragao, L. E., B. Poulter, J. B. Barlow, L. O. Anderson, Y. Malhi, S. Saatchi, O. L. Phillips, and E. Gloor (2014) Environmental change and the carbon balance of Amazonian forests. Biological Reviews 89:913-931.

3. Armando L., Günter H., Yann V (2016) Fast acclimation of freezing resistance suggests no influence of winter minimum temperature on the range limit of European beech, Tree Physiology, 36, 4, 490501

4. Barbour, MM., Cernusak, LA., Whitehead, D., Griffin, KL., Turnbull, MH., Tissue, DT., Farquhar, GD (2005) Nocturnal stomatal conductance and implications for modeling $\delta^{18} \mathrm{O}$ of leaf-respired $\mathrm{CO}_{2}$ in temperate tree species. Functional Plant Biology 32 (12) 1107-1121

5. Bielczynski, LW., Łącki, MK., Hoefnagels, I., Gambin, A., Croce, R (2017) Leaf and Plant Age Affects Photosynthetic Performance and Photoprotective Capacity. Plant Physiology. 175(4):1634-1648. 
6. Brodribb, TJ., Field, TS (2000) Stem hydraulic supply is linked to leaf photosynthetic capacity: evidence from New Caledonian and Tasmanian rainforests. Plant, Cell \& Environment 23: 1381-1388.

7. Chen, JW., Cao, KF., (2015) A possible link between hydraulic properties and leaf habits in Hevea brasiliensis. Functional Plant Biology. 42 (8) 718 - 726

8. Cao MX., Zou M., Warren M., Zhu H (2006) Tropical forests of Xishuangbanna, China. Biotropica, 38: 306-309.

9. Cowan I.R., \& Farquhar GD (1977) Stomatal function in relation to leaf metabolism and environment. In Integration of Activity in Higher Plants (ed. D.H. Jennings), pp. 471-505. Cambridge University Press, Cambridge

10. Cristiano, P.M., Madanes, N., Campanello, P.I., Di Francescantonio, D., Rodríguez, S.A., Zhang, Y.J., Carrasco, L.O., Goldstein, G (2014) High NDVI and potential canopy photosynthesis of South American subtropical forests despite seasonal changes in leaf area index and air temperature. Forests, 5(2), pp.287-308.

11. Drake, JE., Tjoelker, MG., Varhammar, A., Medlyn, BE., Reich, PB., Leigh, A., Pfautsch, S., Blackman, CJ., Lopez, R., Aspinwall, MJ., Crous, KY., Duursma, RA., Kumarathunge, D., De Kauwe, MG., Jiang, M., Nicotra, AB., Tissue, DT., Choat, B., Atkin, OK., Barton CVM (2018) Trees tolerate an extreme heatwave via sustained transpirational cooling and increased leaf thermal tolerance. Global Chang Biology 24:2390-2402.

12. Dungan, RJ., Whitehead, D., McGlone M.,Duncan, RP., Allen RB (2003) Cold-induced photoinhibition and winter leaf-loss in the broad-leaved tree Aristotelia serrata (Elaeocarpaceae). Functional Plant Biology 30 (5) 543-550

13. Dusenge, M.E., Way, D.A (2017) Warming puts the squeeze on photosynthesis - lessons from tropical trees. Journal of Experimental Botany 68, 2073-2077.

14. Farquhar, G. D., O'Leary M. H., Berry J. A. (1982). On the relationship between carbon isotope discrimination and the intercellular carbon dioxide concentration in leaves. Functional Plant Biology 9(2): 121-137.

15. Fauset, S., L. Oliveira, M. S., Buckeridge, C. H., Foyer, D. Galbraith, R., Tiwari, Gloor, M (2019) Contrasting responses of stomatal conductance and photosynthetic capacity to warming and elevated $\mathrm{CO}_{2}$ in the tropical tree species Alchornea glandulosa under heatwave conditions. Environmental and Experimental Botany 158:28-39.

16. Frenne, P., Zellweger, F.,Rodríguez-Sánchez F., Scheffers B, Hylander K., Luoto M., Vellend M, Verheyen K., Lenoir J (2019) Global buffering of temperatures under forest canopies. Nature Ecology \& Evolution. 3. 1.

17. Field, C. (1983) Allocating leaf nitrogen for the maximization of carbon gain leaf age as a control on the allocation program. Oecologia 56:341-347.

18. Field, C. B. (1987) Leaf-age defects on stomatal conductance. In: Zeiger E, Farquhar GD, Cowan I (eds) Stomatal function. Stanford University Press, Stanford, pp 367-384. 
19. Gentine, P., Massmann, A., Lintner, B. R., Hamed Alemohammad, S., Fu, R., Green, J. K., Kennedy, D., and Vilà-Guerau de Arellano, J (2019) Land-atmosphere interactions in the tropics - a review, Hydrology and Earth System Sciences., 23, 4171-4197

20. Gitelson, A. A., Y. Peng, T. J. Arkebauer, and J. Schepers (2014) Relationships between gross primary production, green LAl, and canopy chlorophyll content in maize: Implications for remote sensing of primary production. Remote Sensing of Environment 144:65-72.

21. Granier, A. (1987) Evaluation of transpiration in a Douglas-fir stand by means of sap flow measurements. Tree Physiology 3 :309-319.

22. Hua, Z. (2013) The Floras of Southern and Tropical Southeastern Yunnan Have Been Shaped by Divergent Geological Histories. PLoS ONE 8(5): e64213.

23. Huang, W., Zhang, S.B., Cao, K.F. (2010) The different effects of chilling stress under moderate light intensity on photosystem II compared with photosystem I and subsequent recovery in tropical tree species. Photosynthesis Research 103:175-182

24. Jia, H., Pan, D. (2016) Drought Risk Assessment in Yunnan Province of China Based on Wavelet Analysis. Advances in Meteorology, 2016: 10

25. Kitajima, K., Mulkey, S.S., Wright, S.J. (1997). Decline of photosynthetic capacity with leaf age in relation to leaf longevities for five tropical canopy tree species. American Journal of Botany 84, 702708.

26. Kitajima, K., Mulkey, SS., Samaniego, M., Wright, S.J. (2002). Decline of photosynthetic capacity with leaf age and position in two tropical pioneer tree species. American Journal of Botany 89, 19251932.

27. Korner, C., (2016) Plant adaptation to cold climates. F1000Research 5:2769-2774

28. Kumarathunge, D.P., Medlyn, B.E., Drake, J.E., et al. (2019) Acclimation and adaptation components of the temperature dependence of plant photosynthesis at the global scale. New Phytologist, 222, 768-784.

29. Kumagai T, Ichie T, Yoshimura M., et al. (2006) Modeling $\mathrm{CO}_{2}$ exchange over a Bornean tropical rain forest using measured vertical and horizontal variations in leaf level physiological parameters and leaf area densities. Journal of Geophysics Research 111: 1-16.

30. Landsberg, J., Waring, R., Ryan, M. (2017) Water relations in tree physiology: where to from here? Tree Physiology 37:18-32.

31. Levitt J (1980) Responses of plants to environmental stresses. Physiological ecology, 2nd edition. Academic Press, New York.

32. Li, Longhui; Wang, Yingping; Arora, Vivek; Eamus, Derek; Shi, Hao; Li, Jing; Cheng, Lei; Cleverly, James; Hajima, T; Ji, Duoying; Jones, Chris; Kawamiya, M; Li, Weiping; Tjiputra, J; Wiltshire, Andy; Zhang, Lu; Yu, Qiang (2018) Evaluating global land surface models in CMIP5: analysis of ecosystem water- and light-use efficiencies, and rainfall partitioning. Journal of Climate 1-10 
33. Li, H., Aide, T.M., Ma, Y. et al. (2007) Demand for rubber is causing the loss of high diversity rain forest in SW China. Biodiversity Conservation 16, 1731-1745

34. Li, H., T. M. Aide, Y. Ma, W. Liu, and M. Cao (2006) Demand for rubber is causing the loss of high diversity rain forest in SW China. Biodiversity and Conservation 16:1731-1745.

35. Myers, N., Mittermeier, R.A., Mittermeier, C.G., da Fonseca, G.A.B., Kent, J. (2000) Biodiversity hotspots for conservation priorities. Nature 403:853-858

36. Pan, S., Pan, N., Tian, H., Friedlingstein, P., Sitch, S., Shi, H., Arora, V. K., Haverd, V., Jain, A. K., Kato, E., Lienert, S., Lombardozzi, D., Nabel, JEMS., Ottlé, C., Poulter, B., Zaehle, S., Running, S.W. (2020) Evaluation of global terrestrial evapotranspiration using state-of-the-art approaches in remote sensing, machine learning and land surface modeling, Hydrology and Earth System Sciences, 24, 1485-1509

37. Qiu, J. (2010) China drought highlights future climate threats. Nature 465:142-143.

38. Sack, L., Tyree, M.T. and Holbrook, N.M., 2005. Leaf hydraulic architecture correlates with regeneration irradiance in tropical rainforest trees. New Phytologist, 167(2),403-413.

39. Santanoo S., Vongcharoen K., Banterng P., Jogloy S., Roytrakul S., Theerakulpisut P (2019) Seasonal Variation in Diurnal Photosynthesis and Chlorophyll Fluorescence of Four Genotypes of Cassava (Manihot esculenta Crantz) Under Irrigation Conditions in a Tropical Savanna Climate. Agronomy. 9. 206.

40. Santiago, L.S., Goldstein, G., Meinzer, F.C., Fisher, J.B., Machado, K., Woodruff, D., Jones, T. (2004) Leaf photosynthetic traits scale with hydraulic conductivity and wood density in Panamanian forest canopy trees. Oecologia 140: 543-550.

41. Siddiq, Z., YJ Zhang, SD Zhu, and Cao KF (2019) Canopy water status and photosynthesis of tropical trees are associated with trunk sapwood hydraulic properties. Plant Physiology and Biochemistry 139:724-730.

42. Siddiq, Z., and Cao, KF (2018) Nocturnal transpiration in 18 broadleaf timber species under a tropical seasonal climate. Forest Ecology and Management 418:47-54.

43. Siddiq, Z., Chen YJ, Zhang, YJ., Zhang, JLand Cao, KF (2017) More sensitive response of crown conductance to VPD and larger water consumption in tropical evergreen than in deciduous broadleaf timber trees. Agricultural and Forest Meteorology 247:399-407.

44. Siddiq, Z., Cao, K.F. (2016) Increased water use in dry season in eight deiperocarp species in a common plantation in the northern boundary of Asian tropics. Ecohydrology 9, 871-881.

45. Singh, D., Slik, J.W.F., Jeon, Y. et al. (2019). Tropical forest conversion to rubber plantation affects soil micro- \& mesofaunal community \& diversity. Scientific Reports 9,5893

46. Slot, M., Winter, K. (2017). In situ temperature response of photosynthesis of 42 tree and liana species in the canopy of two Panamanian lowland tropical forests with contrasting rainfall regimes. New Phytologist 214:1103-1117.

47. Slot, M., Winter, K., Timothy Paine CE (2017) High tolerance of tropical sapling growth and gas exchange to moderate warming. Functional Ecology 32:599-611. 
48. Slot, M., and K. Winter. (2017). In situ temperature response of photosynthesis of 42 tree and liana species in the canopy of two Panamanian lowland tropical forests with contrasting rainfall regimes. New Phytol 214:1103-1117.

49. Tan, Z.H., Zhang, Y.P., Liang, N., Hsia, Y.J., Zhang, Y.J., Zhou, G.Y., Li, Y.L., Juang, J.Y., Chu, H.S., Yan, J.H., Yu, G.R. (2012). An observational study of the carbon-sink strength of East Asian subtropical evergreen forests. Environmental Research Letters, 7(4), p.044017.

50. Tucci MLS, Erismann NM, Machado EC, Ribeiro R (2010) Diurnal and seasonal variation in photosynthesis of peach palms grown under subtropical conditions. Photosynthetica 48: 421- 429.

51. Vongcharoen K., Santanoo S., Banterng P., Jogloy S., Vorasoot N., Theerakulpisut, P. (2018) Seasonal variation in photosynthesis performance of Cassava at two different growth stages under irrigated and rain-fed conditions in a tropical savanna climate. Photosynthetica. 56, 1398-1413.

52. Way, D.A., Oren, R., Kroner, Y (2015) The space-time continuum: the effects of elevated CO2 and temperature and the importance of scaling. Plant Cell and Environment. 38, 991-1007.

53. Yang,Y., Chang, W., Huang, W. et al. (2017) The effects of chilling-light stress on photosystem I and II in there Paphiopedilum species. Botanical Studies 58, 53.

54. Yang, S.J., Zhang, Y.J., Sun, M., Goldstein, G., Cao, K.F. (2012) Recovery of diurnal depression of leaf hydraulic conductance in a subtropical woody bamboo species: embolism refilling by nocturnal root pressure. Tree Physiology 32: 414-422.

55. Zhang L., Xiao, J., Li, J., Wang, K., Lei, L., Huadong, G. (2012) The 2010 spring drought reduced primary productivity in southwestern China. Environmental Research Letters 7:045706

56. Zhang, L., Y. Kono, and S. Kobayashi. 2014a. The process of expansion in commercial banana cropping in tropical China: A case study at a Dai village, Mengla County. Agricultural Systems 124:32-38.

57. Zhang, MG., Zhou, ZK., Chen, WY., Cannon, CH., Raes, N., Slik, JWF (2014b) Major declines of woody plant species ranges under climate change in Yunnan, China. Diversity and Distributions. 20, 405415.

58. Zhang, L., Y. Kono, S. Kobayashi, H. Hu, R. Zhou, and Qin, Y (2015). The expansion of smallholder rubber farming in Xishuangbanna, China: A case study of two Dai villages. Land Use Policy 42:628634.

59. Zhang, Q., Yao, Y., Wang, Y. et al. (2019) Characteristics of drought in Southern China under climatic warming, the risk, and countermeasures for prevention and control. Theoretical and Applied Climatology 136, 1157-1173.

60. Zhang, Y.J., Sack, L., Cao, K.F., Wei, X.M. and Li, N (2017) Speed versus endurance tradeoff in plants: Leaves with higher photosynthetic rates show stronger seasonal declines. Scientific reports, 7 , p.42085.

61. Zhang, Y.J., Cristiano, P.M., Zhang, Y.F., Campanello, P.I., Tan, Z.H., Zhang, Y.P., Cao, K.F. and Goldstein, G (2016) Carbon economy of subtropical forests. In Tropical Tree Physiology (pp. 337-355). Springer, Cham. 
62. Zhang, Y. J., N. M. Holbrook, Cao, KF (2014a) Seasonal dynamics in photosynthesis of woody plants at the northern limit of Asian tropics: potential role of fog in maintaining tropical rainforests and agriculture in Southwest China. Tree Physiology 34:1069-1078.

63. Zhang, YP., Sha, LQ., Yu, GR., et al. (2006) Annual variation of carbon flux and impact factors in the tropical seasonal rain forest of Xishuangbanna, SW China. Science in China Series D: Earth Series 49:150-162

\section{Figures}



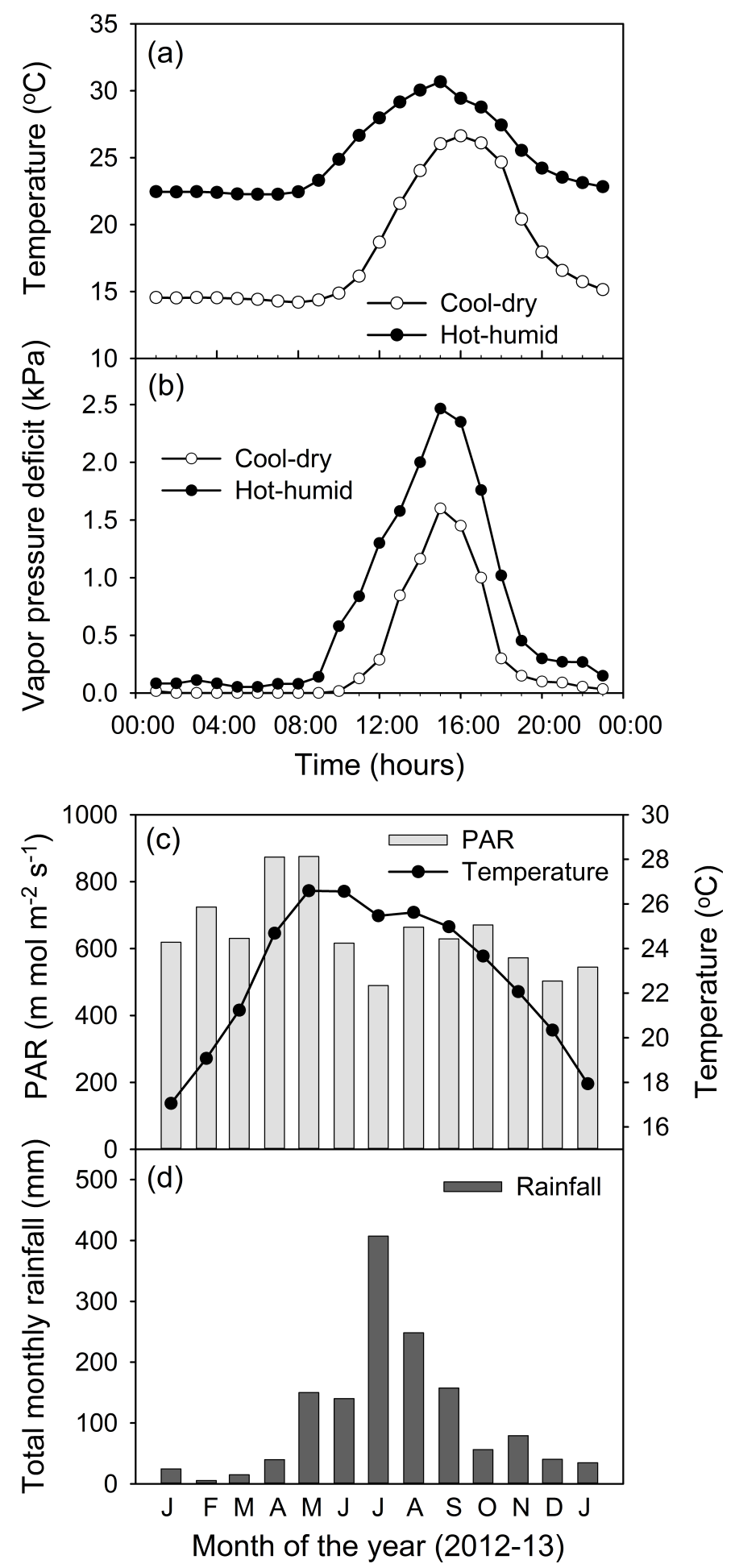

\section{Figure 1}

Diurnal changes in average temperature (a) and vapor pressure deficit (VPD) of the cool-dry season (January) and hot-humid season (September);(b) Seasonal dynamics in average monthly temperature, photosynthetic active radiations (PAR) and (c) Seasonal dynamics in total monthly rainfall during the year of measurements. 


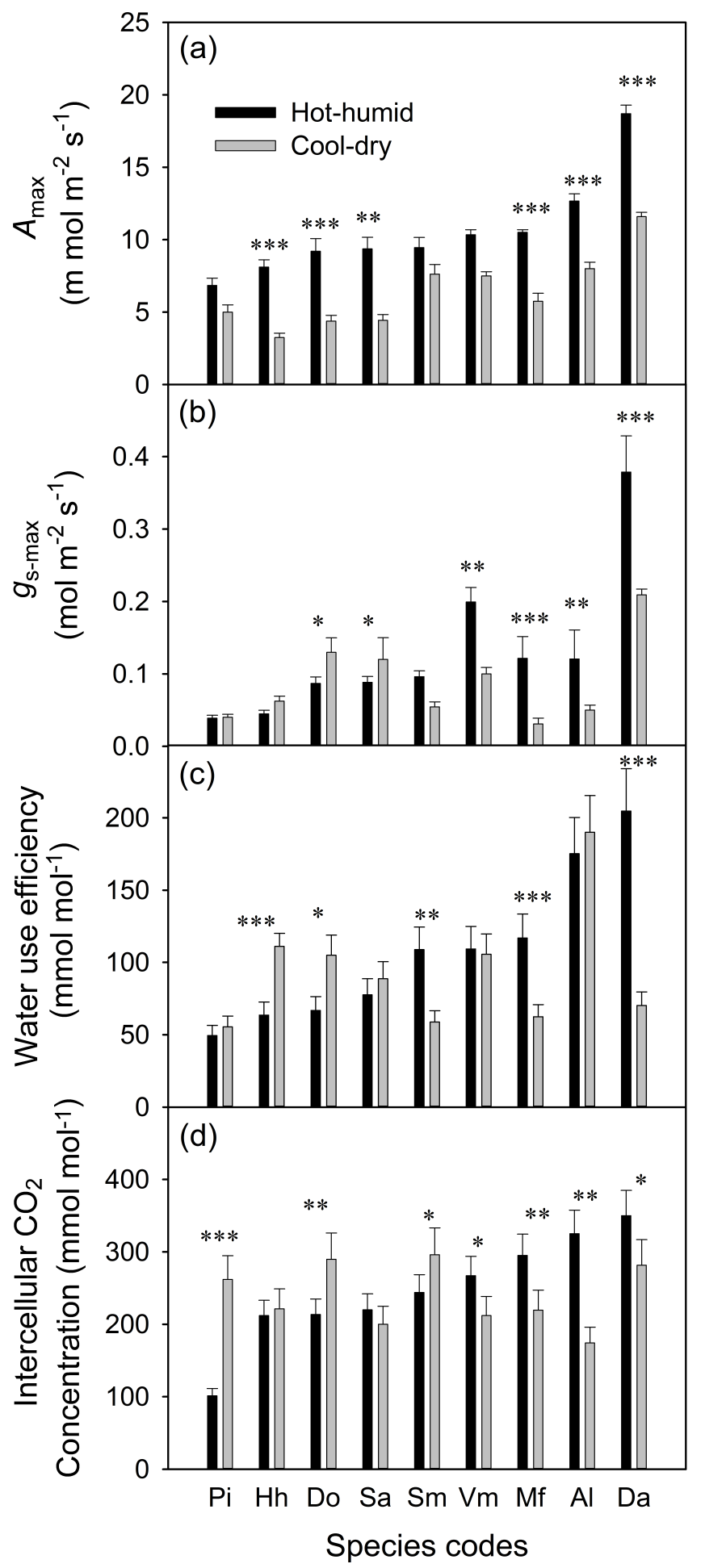

Figure 2

Maximum photosynthetic rate (Amax, a), stomatal conductance (gsmax, b), water use efficiency (c) and intercellular $\mathrm{CO} 2$ concentration (d) of nine tropical tree species in the hot-humid and cool-dry seasons. Where: ${ }^{\star \star *} P<0.0001$, ${ }^{\star *} P<0.001,{ }^{*} P<0.01$, ns indicate non-significance. Bars indicate species means + SEs and the asterisks indicate the significant seasonal differences in the individual species. Species codes are listed in Table 1. 


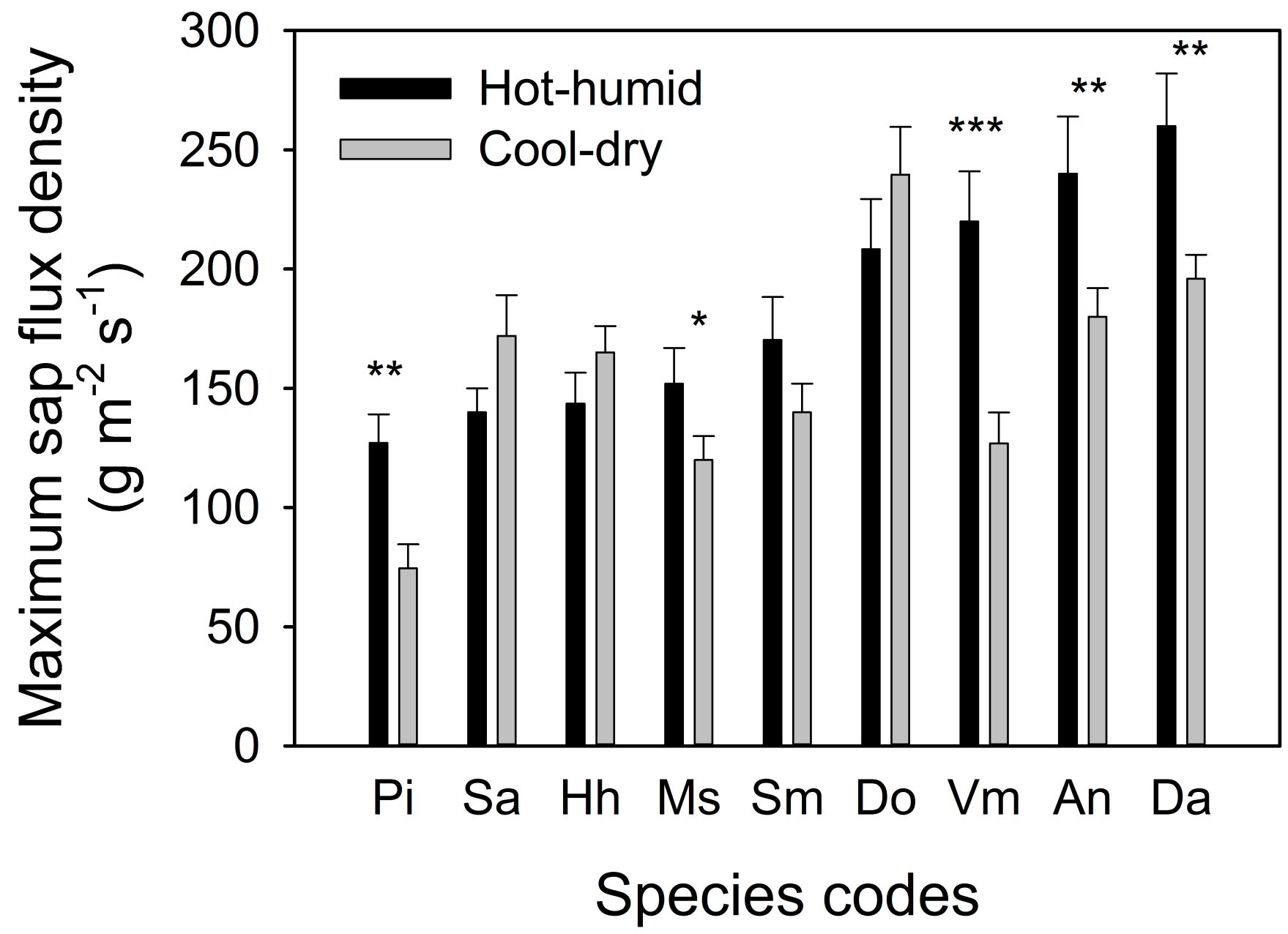

Figure 3

Maximum sap flux density in the hot-humid and cool-dry seasons of nine tropical tree species. Species codes are listed in Table 1. Where: $* \star * P<0.0001, * \star P<0.001, * P<0.01$, ns indicate non-significance. Bars are species means $+S E s$, the asterisks indicate the significant seasonal differences in the individual species. 


\section{Species codes}

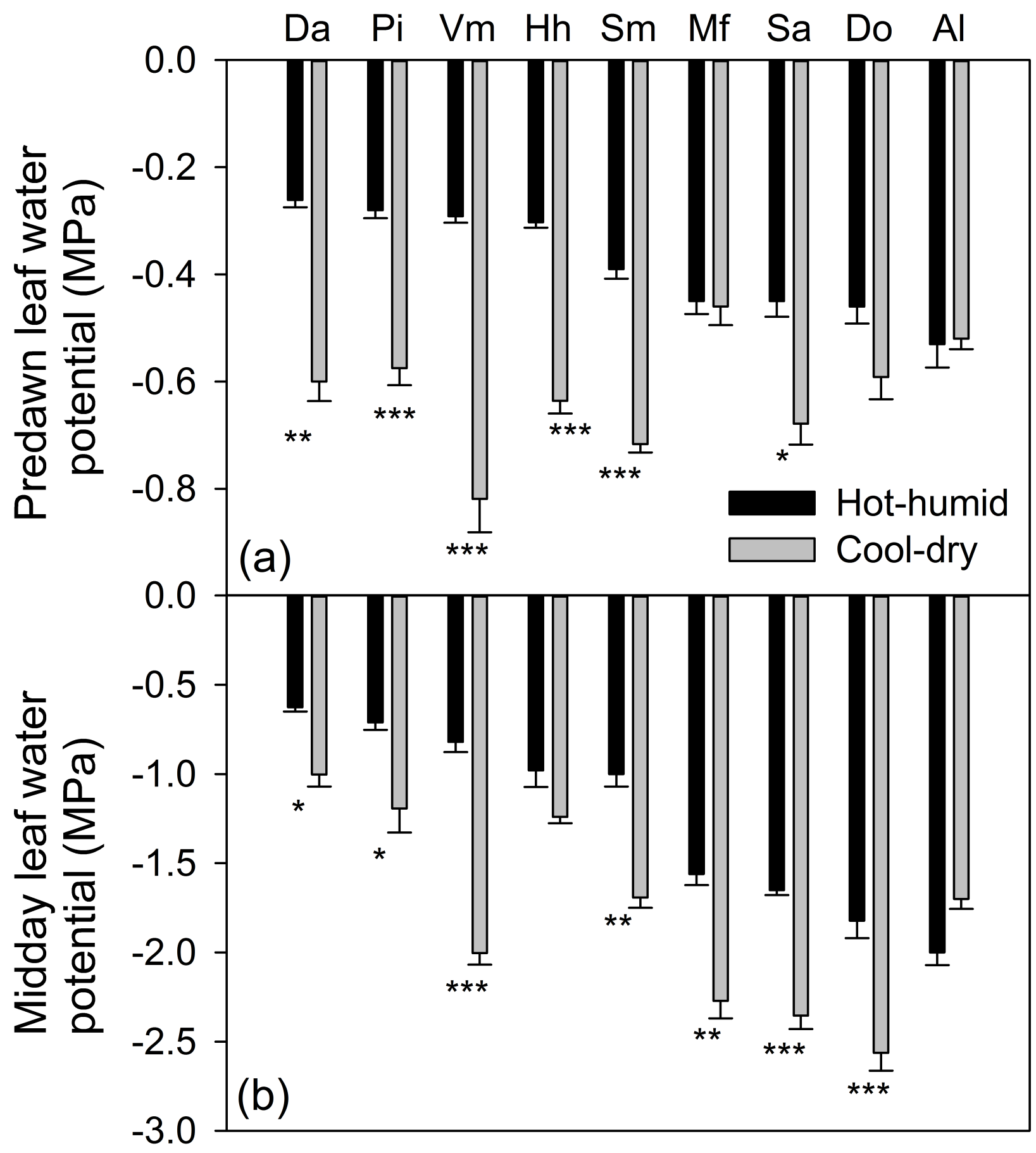

Figure 4

Predawn leaf water potential (a) and midday leaf water potential (b) in the hot-humid and cool-dry seasons. Species codes are listed in Table 1. Where: $* \star \star P<0.0001$, $* * P<0.001$, ${ }^{*} P<0.01$. Bars indicate species means $+\mathrm{SEs}$ and the asterisks indicate the significant seasonal differences in the individual species. 


\section{Figure 5}

The relationship between percent seasonal decline in Amax and gs-max from the hot-humid to the cooldry season across nine tropical tree species studied. The line is a linear regression fitted to the data. Where: ${ }^{*} P<0.001$.

\section{Figure 6}

Maximum photosynthetic rate (a ; Amax) and stomatal conductance (b; gs-max) in relation to maximum sap flux density in hot-humid season (open dots) and cool-dry season (closed dots) across the studied species. Solid lines are linear regressions fitted to the hot-humid season data and the dashed line is a linear regression fitted to the cool-dry season data. Where: ${ }^{*} P<0.001, * P<0.01$, ns indicates that the relationship during the cool-dry season between gs and sap flux density was not significant. 